\title{
IN VITRO ANTIBACTERIAL ACTIVITY OF CEFADROXIL CAPSULES CONSUMED BY PATIENTS IN THE HOSPITAL
}

\author{
Mahfudz $^{1,2}$, Suharjono ${ }^{3 *}$, Isnaeni ${ }^{4}$, Primadi Avianto ${ }^{1}$ \\ ${ }^{1}$ Magister of Clinical Farmacy Student, Faculty of Farmacy, Universitas Airlangga, \\ ${ }^{2}$ Pharmacy Section, Bangka Tengah District Health Office, Bangka Belitung, Indonesia, \\ ${ }^{3}$ Department of Clinical Pharmacy, Faculty of Farmacy, Universitas Airlangga, \\ ${ }^{4}$ Department of Pharmaceutical Chemistry, Faculty of Farmacy, Universitas Airlangga, \\ Gedung Nanizar Zaman Joenoes, Universitas Airlangga \\ Mulyorejo, Surabaya, 60115, Indonesia
}

Received October 15, 2019; Accepted April 29, 2021

\begin{abstract}
Clinical use of cefadroxil, particularly in Bangka Tengah Hospital, is proven beneficial to overcome mild to moderate infections which especially occur in soft tissues such as skin, upper respiratory tract, pharyngitis, tonsillitis and urinary tract. For this reason, it is necessary to procure cefadroxil to be available enough for the treatment of cases of these diseases. The cefadroxil used by the Central Bangka Hospital was obtained from several pharmaceutical industries with different prices and distributions, due to the possibility that the active raw materials and ingredients had different origins, so there was concern that the microbiological quality would be different. Drug procurement is carried out using the e-catalog or non-e-catalog method. This study aimed to examine the microbiological quality of six preparations $(\mathrm{A}, \mathrm{B}, \mathrm{C}, \mathrm{D}, \mathrm{E}$, and $\mathrm{F})$ in terms of their inhibitory activities against Gram-positive and Gram-negative bacteria. The bioassay was carried out by diffusion agar method using Escherichia coli ATCC 29522 and Staphylococcus aureus ATCC 29523 as the bacterial test, and nutrient agar as the test medium. The inhibitory activities were compared to cefadroxil standard for measuring the ratio potency. The results showed that all samples fulfilled USP 41 requirements with potential ratio of $90 \%$ to $120 \%$ and minimum inhibitory concentration of $\leq 8 \mathrm{ppm}$ and $\leq 2 \mathrm{ppm}$ against Escherichia coli and Staphylococcus aureus respectively. The potency ratios to cefadroxil standard were $95.9 \%, 99.1 \%$, $100.0 \%, 96.7 \%, 96.2 \%$ and $98.2 \%$ against Staphylococcus aureus while the potency ratios of 95.6\%, 99.3\%, 103.8\%, 97.1\%, 95.7\% and 100.4\% were achieved against Escherichia coli for A, $\mathrm{B}, \mathrm{C}, \mathrm{D}, \mathrm{E}$, and F samples, respectively.
\end{abstract}

Keywords: Cefadroxil; potency ratio; Escherichia coli; Staphylococcus aureus

\section{INTRODUCTION}

Cefadroxil belongs to the first generation of cephalosporins besides cephradine, cephalexin, cefazoline, cephapirin and cephalothin. In Indonesia, the first generation of cephalosporin preparations available and included in the National Formulary are cefadroxil and cephalexin whereas only one ecatalog namely e-katalog.lkpp.go.id is included in the e-catalog system. Cefadroxil is prescribed for the treatment of mild to moderate infections in soft tissues such as skin, upper respiratory tract, pharyngitis, tonsillitis and urinary tract with a dose of 500 to 1000 mg/day (Brayfield, 2014; Micromedex, 2018). The use of cefadroxil capsules in the first level health facilities (FKTP-Fasilitas Kesehatan Tingkat Pertama) is very limited (Kemenkes, 2017).

The number of planned drug requirements (RKO-Rencana Kebutuhan Obat) in Bangka Belitung Islands provincial health office for 
cefadroxil capsules is still high, reaching 294,804 in 2018 (Dinkes, 2018). The price of cefadroxil per $500 \mathrm{mg}$ capsule in the e-catalog for government procurement and BPJS since 2018 is $\mathrm{Rp} 488$, which is valid from January $10^{\text {th }}, 2018$, until April $3^{\text {rd }}, 2021$ (LKPP, 2018).

The price is far different from what is written on the Decree of the Minister of Health of the Republic of Indonesia Number 094/Menkes/SK/II/2012, regarding the price of medicines for government procurement in 2012 which was Rp840. This price for the government was already lower than the Highest Retail Price (HET) in the same year. Based on the Government Regulation of the Republic of Indonesia Number 32 of 1991 (Anonymous, 1991) concerning import of raw materials, cefadroxil is one of those commodities that is allowed to be imported.

Cefadroxil price reduction of more than $41 \%$ by the Government Goods and Services Procurement Policy Agency in 2018 compared to 2012 prices forced pharmaceutical wholesalers (PBF-Pedagang Besar Farmasi) to reduce relevant fees, especially in shipping drugs to users. Direct procurement of drugs to the pharmaceutical industry can be done through e-purchasing systems. The industry appoints PBF to approve a purchase contract. Large price reductions triggered a concern over the quality of drugs (Dwiaji et al., 2016). The microbiological activity test on six brands of cefadroxil capsules consumed by patients in Bangka Belitung Hospital is a strategic step to ensure the safety of the drug before it reaches the patient. This research is an experimental study to examine in vitro differences among the six different cefadroxil capsules purchased through e-catalogs and non-e-catalogs (LKPP, 2018; MIMS Indonesia, 2018). Significant price differences of the drugs between those obtained through e-catalog and non-e-catalog may indicate differences in quality as well, especially in their microbiological quality. Therefore, this study was conducted to ensure that there were no differences in microbiological quality between the products.

\section{MATERIALS AND METHODS Antibiotics}

The six $500 \mathrm{mg}$ cefadroxil capsule samples were obtained from both e-catalog and non-e-catalog. The e-catalog cefadroxil samples were purchased from the Pharmacy Installation Division and Central Bangka District Hospital, Bangka Belitung Province while the non-e-catalog ones were obtained from the Central Bangka Regency Hospital. Each sample was collected for as many as 100 capsules with the same batch number to compare the pharmaceutical grades of cefadroxil (PT. New Interbat), Dimethylsulfoxidep.a (Merck).

\section{Test bacteria}

Staphylococcus aureus ATCC 25923 and Escherichia coli ATCC 29522 (Letter of statement No 115/301.25/XI/2018) were obtained from the Laboratory of Clinical Microbiology, Dr. Soetomo Hospital. Sodium chloride $0.9 \%$ was used for preparation of the test bacteria. Spectrophotometer Termo Fischer Scientific Type Genesys 20 was used to measure optical density $(580 \mathrm{~nm})$ of the test bacteria suspension to obtain $25 \% \mathrm{~T}$ (CLSI, 2015).

\section{Preparation of test media}

Mueler Hinton agar and broth (Difco) were used for antibacterial activity assays. Three grams of media powder was added with $150 \mathrm{~mL}$ distilled water, heated while stirring evenly, and sterilized with an autoclave at $120^{\circ} \mathrm{C}$ for 15 minutes. Media poured in petri dishes at $40^{\circ} \mathrm{C}$ to $50^{\circ} \mathrm{C}$ were then left solid to be used as a base layer. Seed layer media were prepared by inoculating a $5 \mu \mathrm{L} 25 \%(258 \mathrm{~nm})$ $\mathrm{T}$ test microbial suspense containing $10^{9} \mathrm{CFU}$ and poured over the surface of the compacted media layer (ICH, 2005).

\section{Minimum inhibitory concentration}

In vitro antibacterial activity was evaluated using agar diffusion method on the Muller Hinton agar using a hole as reservoir. The minimum inhibitory concentration (MIC) was determined by a serial dilution on Muller Hinton broth media containing serial of 
twofold a test solution. The MIC was measured after 18 to 22 hours of incubation at $35+1{ }^{\circ} \mathrm{C}$.

\section{Potency ratio of antibiotics}

The ratio of antibiotic potential in the sample to the cefadroxil standard was measured by a 3-3 design according to Farmakope Indonesia-III (Kemenkes, 1979). Three levels of test on samples and three levels of standard namely higher $(\mathrm{H})$, medium $(\mathrm{M})$, and lower (L) concentration solutions were achieved. The tests were carried out using agar diffusion method with a hole as reservoir. Statistical analysis of the data obtained was performed by one-way ANOVA from block random design.

\section{RESULTS AND DISCUSSION}

The inhibition of measurement of the sample solution and cefadroxil standard was carried out in a petri dish to obtain the same condition with negative control or DMSO used as a solvent (Figure 1). The minimum inhibitory concentration (MIC) was determined based on the smallest level that can inhibit the growth of test bacteria compared to positive control from cefadroxil standard (Table 1). Determination of the MIC was useful for setting lower concentration in determining the ratio of antibiotic potential (Table 2 and 4) to the standard. The lower concentration (L) should be higher than the MIC value.

Table 1. Average of minimum inhibition concentration of six samples against $S$. aureus and E. coli

\begin{tabular}{ccccccc}
\hline Test Bacteria & \multicolumn{6}{c}{ Minimum Inhibitory Concentration $(\boldsymbol{\mu g} / \mathbf{m L})$} \\
\hline & A & B & C & D & E & F \\
\hline E. coli & 8 & 8 & 8 & 8 & 8 & 8 \\
\hline S. aureus & 2 & 2 & 2 & 2 & 2 & 2 \\
\hline
\end{tabular}

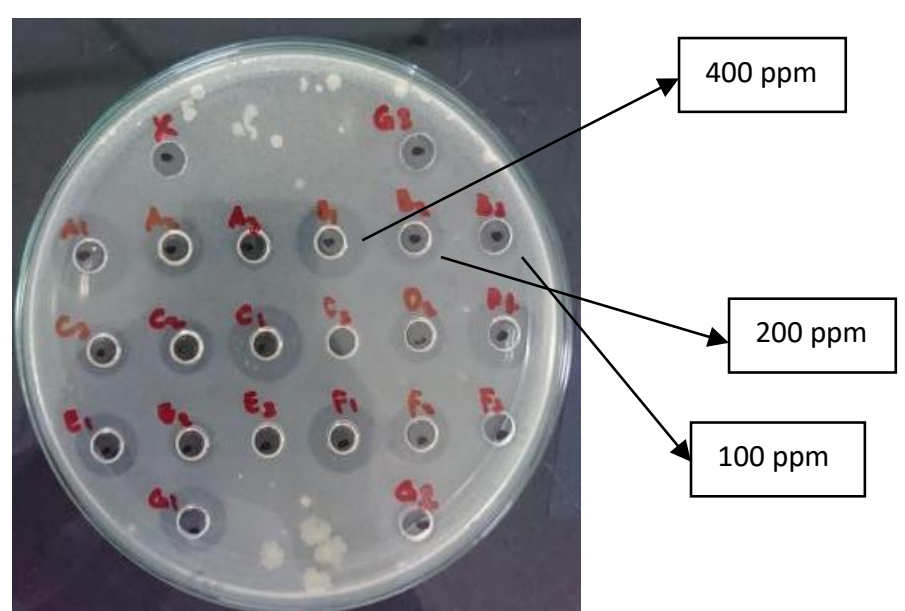

Figure 1. In vitro inhibitory activity of cefadroxil standard $(\mathrm{G})$, samples A, B, C, D, E, F and DMSO (X) after incubation 18 to 22 hours at $35 \pm 1^{\circ} \mathrm{C}$ on Muller Hinton agar media, $S$. aureus as a test bacteria $(\mathrm{ppm}=\mu \mathrm{g} / \mathrm{mL})$.

Note: in the DMSO also created a table in the MIC value, so that readers can see clearly since DMSO can also provide an antibacterial effect. 
Development and validation of a microbiological method for determination of cefadroxil capsules by turbidimetry using $S$. aureus as the test bacteria and brain heart infusion broth as the sulture medium in $3 \times 3$ parallel line assay design reported by De Marco and Salgado (2018) showed satisfactory results. The method was proven to be linear, selective, precise, robust and accurate based on ICH (2005) guidelines in a concentration range of 30 to $120 \mu \mathrm{g} \mathrm{mL}^{-1}$. The developed turbidimetric method is a valid, simple, fast and more economical alternative methodology especially for the routine quality control of cefadroxil in its pharmaceutical dosage form (USP 41, 2018).

The values of turbidity of positive control from cefadroxil reference standard were 0.567 and 0.527 against $S$. aureus and E. coli respectively. The MIC values obtained in this study were $8 \mu \mathrm{g} / \mathrm{mL}$ and $2 \mu \mathrm{g} / \mathrm{mL}$ against $E$. coli and $S$. aureus respectively. The value of MIC against $E$. coli was $\leq 8 \mu \mathrm{g} / \mathrm{mL}$ meaning that the bacteria were still sensitive. A value of $16 \mu \mathrm{g} / \mathrm{mL}$ indicates intermediate and a value of $\geq 32$ means resistant (CLSI, 2015; USP 41, 2018). The bacteria used were standardized strains, so that all bacteria were sensitive to test antibiotics. Calculation of the potency ratio began with the observation of inhibition zones formed around the logging after incubation for 18 to 22 hours at $35+1{ }^{\circ} \mathrm{C}$ at low (L), medium (M) and high (H) concentrations for both test samples and standard solutions (3-3 design) according to Farmakope Indonesia-III (Kemenkes, 1979). Comparison of H:M must be the same as M:L. The results of the zone diameter measurements (Table 2 and Table 4) were calculated with the ANOVA random block design, showing a non-significant difference for all samples at p $>0.05$ (Table 3 and Table 5).

Table 2. Growth inhibitory activity against E. coli

\begin{tabular}{|c|c|c|c|c|c|c|c|c|}
\hline \multirow[t]{2}{*}{ Replication } & \multirow[t]{2}{*}{ Cons. } & \multicolumn{7}{|c|}{ Growth Inhibition Zone Diameter (mm) } \\
\hline & & $\mathbf{A}$ & B & C & D & $\mathbf{E}$ & $\mathbf{F}$ & G \\
\hline \multirow[t]{3}{*}{1} & $\mathrm{H}$ & $18.8 \pm 0.6$ & $18.8+0.8$ & $19.1+0.8$ & $18.2+1.0$ & $18.9+0.5$ & $19.2+0.9$ & $19.7+0.5$ \\
\hline & M & $13.8+0.8$ & $15.2+0.8$ & $14.2+1.4$ & $14.2+1.0$ & $13.8+1.2$ & $15.2+1.7$ & $15.0 \pm 1.1$ \\
\hline & $\mathrm{L}$ & $11.6 \pm 0.6$ & $11.9 \pm 1.0$ & $12.0 \pm 0.7$ & $11.5 \pm 1.0$ & $11.0 \pm 0.9$ & $11.9 \pm 0.9$ & $11.0 \pm 1.1$ \\
\hline \multirow[t]{3}{*}{2} & $\mathrm{H}$ & $19.2 \pm 1.2$ & $18.8 \pm 0.7$ & $19.0+1.1$ & $19.9 \pm 0.7$ & $18.7+1.1$ & $18.7 \pm 1.1$ & $20.3 \pm 0.4$ \\
\hline & $\mathrm{M}$ & $14.0 \pm 0.8$ & $15.2 \pm 0.8$ & $15.5 \pm 0.8$ & $14.1 \pm 1.0$ & $14.1 \pm 1.6$ & $14.7 \pm 1.6$ & $15.1 \pm 1.0$ \\
\hline & $\mathrm{L}$ & $11.6 \pm 0.8$ & $11.8 \pm 0.9$ & $12.2 \pm 1.1$ & $11.2 \pm 0.9$ & $11.5 \pm 0.9$ & $11.5 \pm 0.9$ & $10.0 \pm 0.9$ \\
\hline \multirow[t]{3}{*}{3} & $\mathrm{H}$ & $18.9 \pm 0.8$ & $18.6 \pm 0.5$ & $19.0 \pm 0.8$ & $18.8 \pm 1.2$ & $19.5 \pm 0.9$ & $18.7 \pm 0.9$ & $19.5 \pm 0.5$ \\
\hline & $\mathrm{M}$ & $14.0 \pm 0.9$ & $15.3 \pm 0.9$ & $15.5 \pm 0.8$ & $14.6 \pm 1.3$ & $14.2 \pm 0.9$ & $14.9 \pm 1.5$ & $14.8 \pm 0.9$ \\
\hline & $\mathrm{L}$ & $11.8+0.5$ & $12.0+1.1$ & $12.1+1.2$ & $11.9+0.9$ & $11.3+0.7$ & $11.6+1.2$ & $11.0 \pm 1.1$ \\
\hline Total & & $45.0 \pm 2.6$ & $45.9 \pm 1.5$ & $44.9 \pm 2.7$ & $45.3+2.2$ & $45.3 \pm 2.8$ & $46.9 \pm 3.0$ & $45.5 \pm 2.5$ \\
\hline $\mathrm{p}$ & & $>0.05$ & $>0.05$ & $>0.05$ & $>0, .05$ & $>0.05$ & $>0.05$ & $>0 / 05$ \\
\hline \multicolumn{9}{|c|}{$\begin{array}{l}\mathrm{H}=\text { Higher conc. }(600 \mu \mathrm{g} / \mathrm{mL}), \mathrm{M}=\text { Medium conc. }(300 \mu \mathrm{g} / \mathrm{mL}), \mathrm{L}=\text { Lower conc. }(150 \mu \mathrm{g} / \mathrm{mL}) ; \mathrm{A}, \mathrm{B}, \mathrm{C}, \mathrm{D}, \mathrm{E} \text {, } \\
\mathrm{F}=\text { product codes, } \mathrm{G}=\text { cefadroxil standard }\end{array}$} \\
\hline \multicolumn{9}{|c|}{ 3. Recapitulation statistical analysis by one-way ANOVA against $E$. coli } \\
\hline Product & & A & B & $\mathbf{C}$ & D & $\mathbf{E}$ & $\mathbf{F}$ & STD \\
\hline A & & & 0.558 & 0.273 & 0.999 & 1 & 0.842 & 0.633 \\
\hline B & & 0.558 & & 0.999 & 0.842 & 0.697 & 0.999 & 1 \\
\hline $\mathrm{C}$ & & 0.273 & 0.999 & & 0.558 & 0.391 & 0.965 & 0.997 \\
\hline $\mathrm{D}$ & & 0.999 & 0842 & 0.558 & & 1 & 0.979 & 0.891 \\
\hline E & & 1 & 0.697 & 0.391 & 1 & & 0.925 & 0.766 \\
\hline $\mathrm{F}$ & & 0.842 & 0.999 & 0.965 & 0.979 & 0.925 & & 1 \\
\hline
\end{tabular}


Table 4. Growth inhibitory activity against $S$. aureus

\begin{tabular}{|c|c|c|c|c|c|c|c|c|}
\hline \multirow{2}{*}{$\begin{array}{c}\text { Replicat } \\
\text { ion }\end{array}$} & \multirow[t]{2}{*}{ Cons. } & \multicolumn{7}{|c|}{ Growth Inhibition Zone Diameter (mm) } \\
\hline & & $\mathbf{A}$ & B & $\mathbf{C}$ & $\mathbf{D}$ & $\mathbf{E}$ & $\mathbf{F}$ & $\mathbf{G}$ \\
\hline \multirow[t]{3}{*}{1} & $\mathrm{H}$ & $18.9 \pm 0.7$ & $19.5 \pm 0.3$ & $19.6 \pm 0.5$ & $17.6 \pm 0.7$ & $18.8 \pm 0.7$ & $19.3 \pm 1.1$ & $18.8 \pm 1.1$ \\
\hline & M & $13.6 \pm 0.5$ & $14.7 \pm 0.6$ & $14.7 \pm 1.1$ & $14.7 \pm 0.3$ & $13.7 \pm 0.3$ & $15.5 \pm 1.6$ & $14.8 \pm 1.6$ \\
\hline & $\mathrm{L}$ & $11.2 \pm 1.2$ & $11.7 \pm 1.0$ & $12.4 \pm 0.9$ & $12.8+1.3$ & $11.5 \pm 0.5$ & $12.0 \pm 1.1$ & $10.8 \pm 0.8$ \\
\hline \multirow[t]{3}{*}{2} & $\mathrm{H}$ & $18.5 \pm 1.1$ & $19.1 \pm 0.6$ & $19.1 \pm 1.1$ & $18.6 \pm 0.6$ & $19.4+0.8$ & $19.2 \pm 1.0$ & $20.0 \pm 0.9$ \\
\hline & M & $14.9 \pm 0.2$ & $14.6 \pm 0.5$ & $17.5 \pm 0.7$ & $14.2 \pm 1.1$ & $14.0 \pm 1.2$ & $14.9 \pm 1.6$ & $15.1 \pm 1.4$ \\
\hline & $\mathrm{L}$ & $11.5+1.0$ & $12.0 \pm 0.2$ & $13.7+1.4$ & $12.2+0.7$ & $11.5+1.0$ & $11.8+1.0$ & $11.3+1.1$ \\
\hline \multirow[t]{3}{*}{3} & $\mathrm{H}$ & $18.4 \pm 0.6$ & $18.5 \pm 0.8$ & $18.9 \pm 0.6$ & $18.1 \pm 1.0$ & $18.7 \pm 0.9$ & $18.8 \pm 1,3$ & $20.3 \pm 0,6$ \\
\hline & M & $13.6 \pm 0.9$ & $14.9 \pm 0.4$ & $14.0 \pm 1.4$ & $14.3 \pm 1.1$ & $13.8 \pm 1.3$ & $14.8 \pm 1.6$ & $15.2 \pm 1.3$ \\
\hline & $\mathrm{L}$ & $11.6 \pm 0.6$ & $11.6 \pm 1.2$ & $11.8+0.9$ & $11.5+1.0$ & $11.0+0.9$ & $11.7 \pm 0.7$ & $11.0 \pm 1.0$ \\
\hline Total & & $43.9 \pm 1.9$ & $44.6 \pm 1.4$ & $43.9 \pm 1.6$ & $44.4 \pm 1.6$ & $44.3 \pm 2.0$ & $45.6 \pm 1.7$ & $45.8 \pm 3.2$ \\
\hline $\mathrm{p}$ & & $>0.05$ & $>0.05$ & $>0.05$ & $>0.05$ & $>0.05$ & $>0.05$ & $>0.05$ \\
\hline
\end{tabular}

Table 5. Recapitulation statistical analysis by one-way ANOVA against S.aureus

\begin{tabular}{ccccccccc}
\hline Product & A & B & C & D & E & F & G \\
\cline { 5 - 9 } A & & 0,489 & 0,002 & 0,985 & 1 & 0,192 & 0,305 \\
\hline B & 0,489 & & 0,328 & 0,927 & 0,546 & 0,998 & 1 \\
\hline C & 0,002 & 0,328 & & 0,024 & 0,002 & 0,677 & 0,517 \\
\hline D & 0,985 & 0,927 & 0,024 & & 0,992 & 0,654 & 0,799 \\
\hline E & 1 & 0,546 & 0,002 & 0,020 & & 0,228 & 0,352 \\
\hline F & 0,192 & 0,998 & 0,677 & 0,654 & 0,228 & & 1 \\
\hline
\end{tabular}

Table 6. Ratio of potency between antibiotic in the six samples and cefadroxil standard against $S$. aureus and E. coli

Test Bacteria

\begin{tabular}{lcc}
\hline \multicolumn{1}{l}{ coli } & A & B \\
aureus & 95.9 & 99.1 \\
\hline & 95.6 & 99.3 \\
\hline & & \\
& The inhibition of all samples against $E$.
\end{tabular}

coli was the same while the inhibition against $S$. aureus for several samples showed different meanings (Table 3 and Table 5). The mean value of inhibition zone diameter against E. coli from sample $\mathrm{D}$ with the highest cefadroxil concentration $(\mathrm{H})$ showed the smallest diameter of $18.2+1.0 \mathrm{~mm}$. The inhibition zone diameter of $E$. coli was smaller than the diameter of the inhibition zone against $S$. aureus with the cefadroxil test solution at the same concentration. This phenomenon occurs due to differences in the wall structure of Gram-positive and Gramnegative bacteria. The structure of Grampositive bacterial walls is single-layered and Gram-negative is multi-layered (multi) during the mechanism of action of cefadroxil through inhibition of cell wall synthesis (Grayson et al., 2018). Antibiotics were 
categorized as sensitive with a $30 \mu \mathrm{g}$ well hole if it has a diameter value of $\geq 18 \mathrm{~mm}$, intermediate if the diameter value is 15 to 17 $\mathrm{mm}$, and resistant if it is $\leq 14 \mathrm{~mm}$ (CLSI, 2015).

The results of the calculation of the potential ratio compared to the standard were according to Farmakope Indonesia-III (Kemenkes, 1979). Referring to Table 6, it can be concluded that potential ratios were declared to meet USP 41 (2018) requirements which specify acceptance criteria of cefadroxil capsule potentials for not less than $90 \%$ and greater than $120 \%$. The potential ratio compared to the cefadroxil standard $(\mathrm{G})$ generated the values of $95.9 \%$ to $100.0 \%$ and $95.6 \%$ to $103.8 \%$ (Table 6) against E. coli and $S$. aureus respectively. The $500 \mathrm{mg}$ cefadroxil capsules that were tested indicated that all samples met the standard of both potential ratio and MIC. This finding indicated that the drugs distributed at the health center or puskesmas and Bangka Tengah Hospital met the requirements. Drugs procured by epurchasing are in principle safer than counterfeiting because they are carried out by procurement officers directly to the desired pharmaceutical industry. So, those who make agreements or contracts are not PBF. Drugs that have been announced on the e-purchasing system have gone through administrative selection especially related to eligibility requirements (LKPP, 2018).

Research on the potency of microbiological and chemical content of active substances of some cefadroxil capsules has never been done in Indonesia. Meanwhile, in Pakistan there has been a study comparing the microbiological potential of six cefadroxil capsules using $S$. aureus and E. coli germ isolates (Rahim et $a l ., 2014$ ) and content examination by HPLC (Rahim et al., 2015). Rahim et al. (2013) also reported that seven brands of cefadroxil monohydrate have been evaluated using set quality control test of weight variation, hardness, disintegration, dissolution and assay with the intention to judge whether these seven brands are pharmaceutically equivalent with USP standard.

\section{CONCLUSION}

The potential ratio of the six cefadroxil $500 \mathrm{mg}$ capsule brands to the cefadroxil standard meets USP 41 requirements. Minimum inhibitory concentration of all six brands of cefadroxil capsule products is the same and fulfills sensitive criteria based on CLSI guideline.

\section{REFERENCES}

Anonim, 1991. PeraturanPemerintah Republik Indonesia Nomor 32 Tahun 1991 Tentang Bahan Baku atau Produk Tertentu yang Dilindungi Paten Bagi Produksi Obat Di Dalam Negeri, Jakarta.

Brayfield A., 2014. Martindale: The Complete Drug Reference. $38^{\text {th }}$ Edition, Pharmaceutical Press, 1, 234247.

De Marco BA., Salgado HRN., 2018. Rapid Stability-indicative Turbidimetric Assay to Determine the Potency of Cefadroxil Monohydrate Capsules. Analytical Method. 6, 1-7.

Dinkes, 2018. Rencana Kebutuhan Obat Provinsi Kepulauan Bangka Belitung, Pangkalpinang.

Dwiaji A., Prih S., Hasbullah,Muhammad S., 2016. Evaluasi Pengadaan Obat Publik Pada JKN Berdasarkan Data eCatalogue Tahun 2014-2015. Jurnal Ekonomi Kesehatan Indonesia, 1(1), 39-53.

Grayson ML., Cosgrove SE., Crowe S., Hope W., McCarthy JS., Mills J., Mouton JW., PatersonDL., 2018. Kucers' The Use of Antibiotics: A Clinical Review Antibacterial, Antifungal, Antiparasitic, and Antiviral Drugs, 7th Edition - Three Volume Set, 370-376.

ICH, Harmonised Tripartite Guideline, 2005.Validation of analytical procedures: text and methodology-Q2 (R1), in: Proceedings of International 
Conference on Harmonisation, The Switzerland.

Kementerian Kesehatan RI, 1979, Farmakope Indonesia III. Jakarta.

Kementerian Kesehatan Republik Indonesia.

Kementerian Kesehatan RI, 2012. Keputusan Menteri Kesehatan Republik Indonesia Nomor 094/Menkes/SK/II/2012 Tentang Harga Obat Untuk Pengadaan Pemerintah Tahun 2012. Jakarta.

Kementerian Kesehatan, 2014, Farmakope Indonesia V. Jakarta. Kementerian Kesehatan Republik Indonesia.

Kementerian Kesehatan, 2017. Formularium Nasional 2017. Jakarta. Kementerian Kesehatan Republik Indonesia

LKPP, 2018. Peraturan Lembaga Kebijakan Pengadaan Barang/Jasa Pemerintah Nomor 9 Tahun 2018 Tentang Pedoman Pelaksanaan Pengadaan Barang/Jasa Melalui Penyedia. [WWW Document]. URL www.Ekatalog.lkpp.go.id

Micromedex, 2018. Cefadroxil. Micromedex-IBM Watson Health. [WWW Document] URL https://www.micromedexsolutions.co $\mathrm{m} /$ (accessed 3.3.18).

MIMS Indonesia, 2018. [WWW Document]. URL https://www.mims.com.indonesia

Rahim N., Naqvi SBS., Iqbal E., Bashir S., Nesar S., Khaliq UA., Hasan EK., 2013. Investigation on Pharmaceutical Quality of Different Brands of Cefadroxil Monohydrate available in Karachi, Pakistan. Indo American Journal of Pharmaceutical Research, 3(6), 4577-4583

Rahim N., Naqvi SBS., Bashir S., Rafiq K., Nesar S., 2014. Assessment of Different Brands of Cefadroxil for Their in Vitro Antibacterial Activity against Staphylococcus aureus and Escherichia coli. International Journal of Pharmaceutical Science Invention, 3(2), 1-6.
Rahim N., Naqvi SBS., Shakeel S., Iffat W and Muhammad IN., 2015. Determination of Cefadroxil in Tablet/Capsule formulations by a Validated Reverse Phase High Performance Liquid Chromatographic method. Pakistan Journal Pharmaceutical Science, 28(4), 13451349.

The Clinical and Laboratory Standards Institute (CLSI), 2015. M100-S25 Performance Standards for Antimicrobial Susceptibility Testing; Twenty-Fifth Informational Supplement. CLSI document M100S25. Wayne, PA: Clinical and Laboratory Standards Institute, 25th edition.

USP 41, 2018. United States Pharmacopeia. 41th edition. New York. The United States Pharmacopeial Convention. 